\title{
Ida Blom - nordisk kvindehistories grand old lady...
}

\section{Ved Hilda Rømer Christensen}
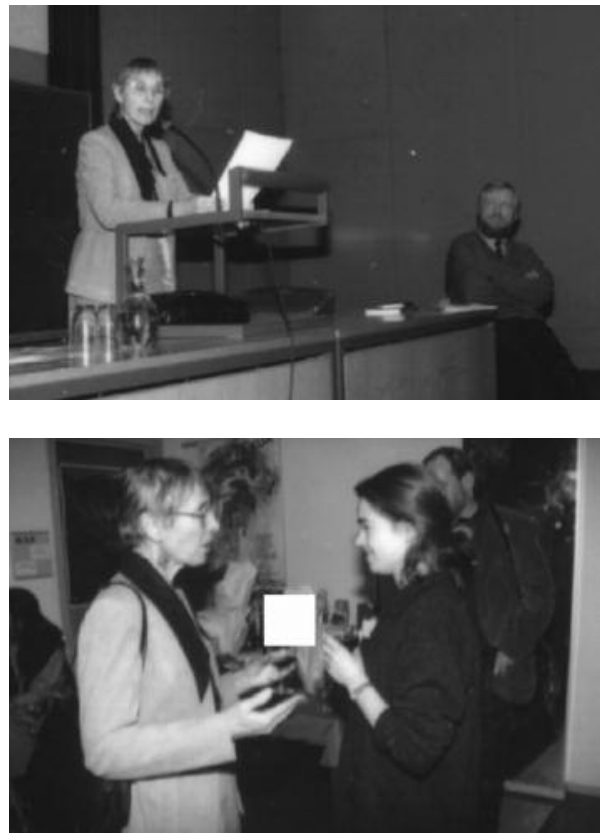

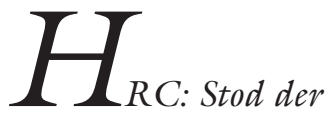

skrevet over din vugge, at du skulle vere professor?

IB: Nej, det kan jeg love dig for at der ikke gjorde. Der stod skrevet at jeg skulle være husmoder og mor og hustru og de der ting, det var det man blev dengang. Jeg er født i 1931. Jeg begyndte med en sekretæruddannelse for det var altid nyttigt. Den varede bare et par år og kunne også til nød kombineres med familie på halv tid. Det vigtigste tror jeg var min egen videbegxrlighed. Jeg havde altid haft lyst til at studere og brugte enhver anledning til at sætte mig hen og læse og studere. Jeg rejste ud, da jeg blev færdig med sekretæruddannelsen og boede i England og Frankrig. Så da jeg i en alder af 23 år og nygift slog mig ned i den lille bitte ravnekrog som hed Bergen, så havde jeg faktisk allerede læst hele pensum til at tage en universitetseksamen i fransk. Det var det første jeg gjorde så tog jeg tysk, som jeg også var vældigt begejstret 


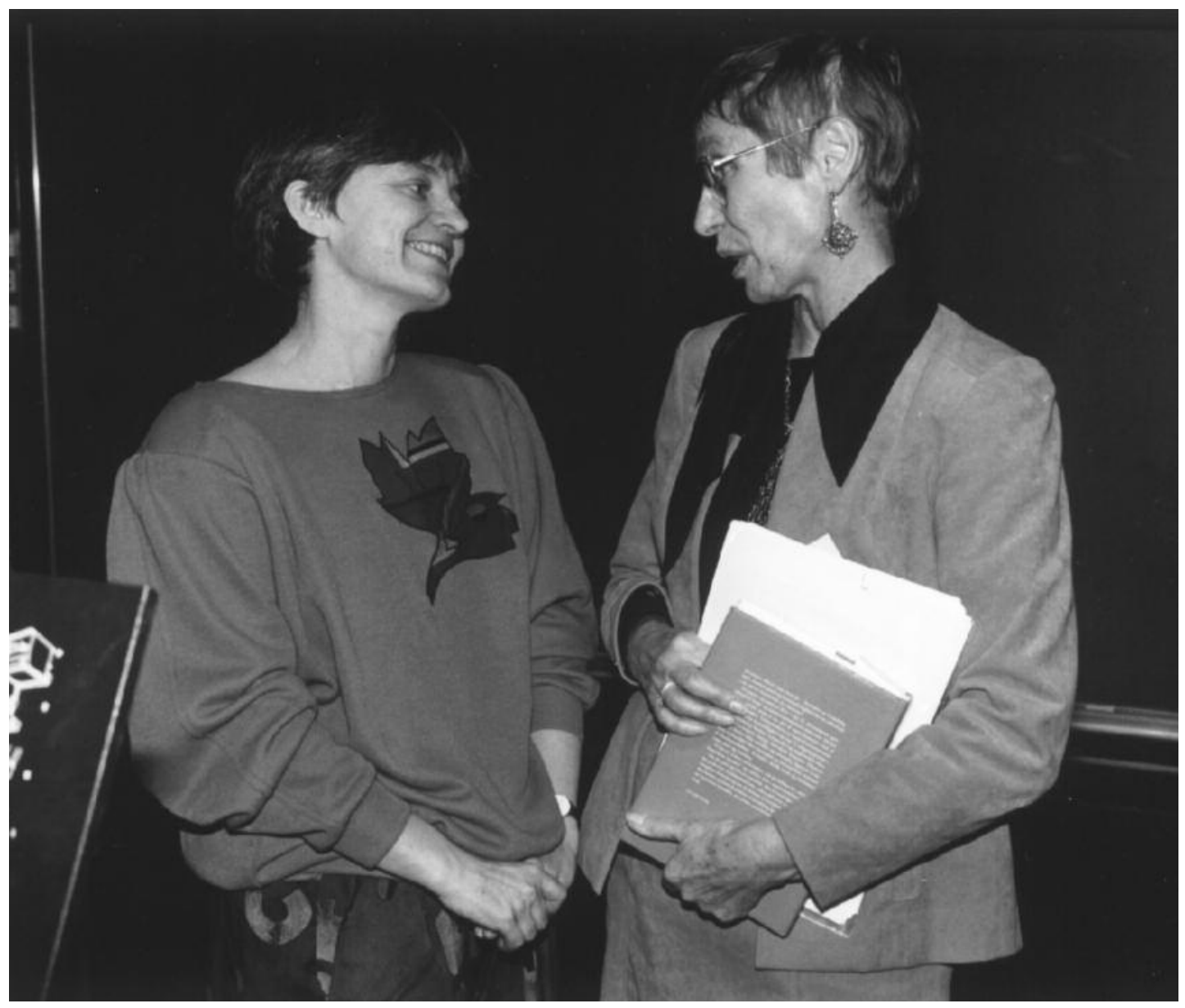

Ida Blom (til hojre) i samtale med Bente Rosenbeck, Kobenhavn 1993.

\section{BLÅ BOG}

IDA BLOM, født 1931 i København. Opvokset i Danmark. Giftede sig og flyttede til Bergen 1954. Cand. Philol. 1960. Dr. Philos.1972. Knyttet til Historisk Institut ved Universitetet i Bergen fra 1961, førstelektor 1969. Udnævnt til professor i kvindehistorie 1985. Medlem af det norske Videnskapsakademi 1993. Udenlandsk medlem af Kungl. Vitterhets historie och antikvitetsakademien i 1996, Æresdoktor ved Københavns Universitet 1996. En af hovedkræfterne bag oprettelsen af Senter for humanistisk Kvindeforskning ved Universitetet i Bergen i 1985. 1987-1995 præsident for the International Federation for Research in Women's History, tilknyttet the International Committee for Historical Sciences.

Deltager i en lang række nordiske og internationale forskningsprojekter, udstrakt forelæsningsvirksomhed. To børn, seks børnebørn.

Publikationer: se listen efter interviewet. 
for som sprog, og da jeg så skulle vælge det tredje fag talte jeg på fignerne mellem engelsk, norsk og historie. Og af grunde, som havde med de lokale lærerkræfter at gøre, blev det historie. Det fængede mig virkelig, jeg syntes det var utroligt spændende. Og noget som vel var vældig vigtigt var gennem at studere det fag og studere det i Norge, så fik jeg et godt indblik i det land som jeg nu havde slået mig ned i. Og forståelse for hvilke mennesker det var, jeg havde bestemt mig for at leve sammen med.

\section{HRC: Kom du fra en akademikerfamilie?}

IB: Min morfar var både teolog og arkitekt. Og havde været missionær mange år i Indien, så der kom det akademiske ind, min mormor var forfatter og skrev børnebøger, så det kom nok ind også der. Min far havde ønsket at læse og blive læge, men der var otte børn og han var den xldste, så det kunne der ikke blive tale om. Han arbejdede i ØK som arkivar, og han havde altså ikke nogen akademisk uddannelse. Min mor begyndt at læse på Zahles Seminarium, men da hun forlovede sig, sagde min morfar: ikke mere uddannelse til dig, for nu skal du jo giftes. Og det angrede hun jo, specielt da hun blev enke med fire børn. Min morfar var ganske kritisk overfor, at min mor lod os tage studentereksamen, fordi hun sad der som enke. Han syntes det var helt unødvendigt, nu kunne vi godt gå ud og tjene nogle penge til vores mor, nu når vi var blevet en 15-16 år. Ifølge ham skulle piger ikke have uddannelse. Men mor sagde: jeg skal støtte dig så meget jeg kan. Men der var ikke penge til at gå på universitetet, det var bare ikke muligt. Desuden tænkte jeg, at jeg skulle giftes. Jeg kunne ikke gå der og studere i 6 år.

\section{HRC: Det der med historiestudiet forte på et tidspunkt til kvindehistorien, hvordan gik det til?}

IB: Ja, i mange år lavede jeg det man kan kalde traditionel politisk historie. Min dok- torafhandling var jo traditionel politisk historie om Grønlandsspørgsmålet. Det som fik mig ind i kvindehistorie var interessant nok en samtidshændelse, nemlig diskussion i Norge i 1972 om, hvorvidt man skulle være med i Fællesmarkedet eller ej. Og der kom det op, at der var nogle lande i Fællesmarkedet, hvor gifte kvinder ikke havde lov at tage sig et job uden at få skriftlig samtykke fra sin xgtefælle. Og jeg opdagede også til min store forskrækkelse at franske kvinder ikke havde haft stemmeret før i 1945. Og det var aldrig faldet mig ind, at der havde været den forskel, og jeg måtte da også til min beskæmmelse erkende, at jeg havde undervist i historie og snakket om almindelig stemmeret uden at tilføje, at det bare var for mænd. For der havde jo dog været nogle kvinder i disse lande, som havde gjort noget.

\section{HRC: Hvordan kom du i kontakt med an- dre kvindehistorikere?}

IB: Jeg vil næsten sige at det kom af sig selv, for når man arbejdede med det perspektiv på faget havde man meget lidt at hente $\mathrm{i}$ sit hjemlige miljø. Så kontakten kom næsten automatisk, når, man kom på de traditionelle konferencer. Det, som for alvor startede det, var et norsk forskningsprojekt, som startede i 1978. Det handlede om kvindearbejde og blev derefter udbygget til et nordisk projekt. Det præsenterede vi på det nordiske historikermøde i Jyväskyla i 1981. Og så fik man kontakter der og derfra udsprang for øvrigt de nordiske kvindehistorikermøder. Det norske forskningråd finansierede også konferencer for kvindeforskning og kvindehistorie, så der var en periode på en 5- 6 år hvor forskningsrådet gjorde utroligt meget. Det var bare om at have nogle gode ideer, så blev de taget op.

HRC: Dernest kom de internationale engagementer $i$ den internaitionale historikerorganisation og senere dannelsen af den internationale kvindehistorikerorganisation. 
IB: Ved verdenskonferencen i Bukarest, som afholdes af den internationale historikerorganisation, var et af hovedtemaerne, uden at nogle at kvindehistorikerne egentlig havde lagt sig i selen for det, "Kvinden $\mathrm{i}$ samfundet”. Og jeg blev spurgt om jeg ville lede denne session. Det var i øvrigt første gang i organisationens historie at en kvinde ledede en heldagssession. De var lige som lidt nervøse, men det gik meget godt. Og her traf mange kvindehistorikere hinanden. Og på den måde begyndte tingene at rulle. Spingbrædtet har været de almindelige historiekanaler, hvor de, der var interesseret i kvindehistorie begyndte at søge sammen.

Fem år efter i 1985, startede vi den internationale kvindehistorikerorganisation, The International Federation for Research in Women's History. Jeg funderede på, hvordan man skulle gå frem, hvis man nu skulle lave sådan en international sammenslutning og skrev et brev til den internationale historikerorganisation, The International Committee for Historical Sciences og spurgte om det. Og det havde så rygtedes $\mathrm{i}$ miljøet og jeg kom i kontakt med canadiske og amerikanske historikere $\mathrm{Og}$ vi bestemte os for at det her skal vi gøre. Og så begyndte bolden at rulle. De tog kontakt med folk i USA og i Canada, og jeg med de folk jeg kendte $\mathrm{i}$ de nordiske lande, og i Tyskland og i England. Men det vigtige var, at det var en lille gruppe af arbejdsomme og begejstrede personer. For dette gjorde man fuldstændig i sin fritid. Der var ikke en øre, så vi sled og vi slæbte med breve osv. Det var tilmed før e-mailens tid.

I dag, når vi er på de internationale kommissionsmøder i historikerorganisationen så står der stor respekt om kvindehistorikerne. Vi har nationale kommiteer i over 25 lande og vi laver gode programmer og vi har ideer og sætter ting i gang, så de der er mænd i ledelsen er begejstrede. De er ikke helt så begejsterede, når vi beklager os over, at der er for få kvinder i ledelsen af den store organisation. Så bliver der jo tusind bes- værligheder. Men altså de vil gerne have, at man gør noget.

HRC: Nair man lober igennem din videnskabelige produktion bliver man belt forpustet. Der er en veldig spendvidde fra traditionel politisk historie, over verker om forskellige kvindehistoriske emner til kvindernes verdenshistorie, et kollektivt verk, der kom i 2 bind $i$ Danmark og bele $3 i$ Norge, og sà her på det sidste talrige bidrag til internationale antologier om kvindebevegelse, velferdsstat og nationalisme. Er du ved at vende tilbage til den politiske historie?

IB: Det kan man på sin vis godt sige. Det, der interesserer mig nu, det er det med nationalisme, nationsbygning og køn i et komparativt perspektiv. Hvor jeg har været optaget af at se på Asien og Europa ud fra bestemte lande og prøve at se om der er nogle frlles mønstre, og hvordan kan man forklare nogle af de store forskelle, som der vitterligt er. Da jeg begyndte på kvindehistorien var det jo samtidigt med at nye områder som historisk demografi, den nye socialhistorie, arbejderbevægelsens historie fik vind i sejlene. I det hele taget kom den kulturelle side af historien op. Lokalhistorien, kvindehistorien var en del af denne græsrodsprægede historie interesse, som gik væk fra politikken på eliteniveau og ønskede at se hvordan politik bliver til mellem almindelige mennesker. Formålet var at se på græsrodsbevægleser som politiske bevægelser, se på hverdagsliv og alt det.

De, som har arbejdet eksplicit med politisk historie og gjorde det dengang, følte sig nok skudt til side af alle de nye ting som kom op. De blev glade, da den politiske historie fik en renæssance, Men det er jo ikke den samme form for politisk historie. Der er jo sket noget, som afspejler netop en slags samtale mellem de forskellige grene af historien. F. eks. kan man i dag dårligt skrive om politik uden at trække på demografi. Der er ikke megen politisk historie man egentlig kan skrive uden at vide noget om de sociale forhold. Det betyder selvfølgelig 
ikke at du ikke kan se på et politisk partis historie eller hvad der skete i rigsdagen. Men man må efter min mening se dette på baggrund af, at det fungerer i et samfund, som er sådan og sådan. $\mathrm{Og}$ det er kommet meget klarere frem end det var i min studietid. Hvor historie var synonym med ren politisk historie.

HRC: Hvordan bliver man ved med at have energi til at folge med, at surfe på de nye metodiske og teoretiske bolger? Hvis vi nu er store $i$ slaget, så hedder det $i$ din tid positivisme, bermeneuitik, marxisme, poststrukturalisme Hvordan undgair man at blive sat og konservativ, at sige stop, nu orker jeg ikke mere?

IB: Nogle gange kan man jo sige åh, det der har jeg hørt før, nu syntes jeg at det kan være nok! Men pointen er at selv om man har hørt det før, så har man ikke hørt det i netop den form. Jeg syntes det er fantastisk fint at kommunikere med unge mennesker, jeg elsker at vejlede på hovedsfagsniveau, det synes jeg er vældigt fint - og de stiller altid spørgsmålene lidt anderledes og de får en til at tænke på nye måder. Og skal den kommunikation fungere, så må man følge med!

Noget andet, som også gør at man ikke bliver træt ligger i selve det at forske. Det, at man aldrig bliver færdig og at man aldrig finder de endelige forklaringer, man finder aldrig den eneste teori der virkelig kan blive stående og forklare ting. Og det er det, der er spændende i en forskningsproces, at man står aldrig på stedet. Det kan måske nok være anstrengende men samtidig er det det, der er inspirerende. For hvis bare skulle sidde og gøre det samme hele tiden, så tror jeg du ville blive træt. Jeg ville f.eks. ikke orke at sidde med patriarkats-teori i 10 år. Der syntes jeg at poststrukturalismen var helt herlig! Samtidig med at den havde en slags forløber i det man hele tiden havde sagt, at kvinder er forskellige, er er jo stor forskel på land og by og klasser og alt det der. Hvis man gør det lidt banalt, så kan man sige, at der lå noget, man hele tiden havde vidst, men de nye teorier gav det en anden kraft som bragte ny indsigt og en lidt anden måde at arbejde på. Jeg forventer ikke af mig selv at jeg skal begynde at læse Derrida eller andre franske filosoffer for at kunne arbejde med mit eget fag. $\mathrm{Hi}^{-}$ storie er et fag i sig selv, det har sin metode og sine fremgangsmåder og det er min kerne. Men jeg henter noget inspiration rundt omkring fra, og jeg leger så med disse ting. Jeg tager dem altså ikke så forfærdeligt højtideligt. Hvis man virkelig ville deltage i den filosofiske debat, måtte man bruge år på at sætte sig ind i nyt stof og nye metoder.

HRC: Det at vere historiker indeberer et voldsom dokumentaionskrav. At vere historiker krever at man trawler igennem veldige mangder af stof. Hvordan haindtever du denne forskningsproces, som krever overblik og ekstrem fordybelse.

IB: Rent teknisk har PCen jo været en kolossal hjælp, fordi det har lettet skriveprocessen.

Men det har også noget at gøre med, om man trives med at sidde i støvede arkiver og bladre i papirer og tage notater og opføre sig som en detektiv og finde ud af hvem der foretog sig noget hvornår, hvor og hvorfor. Det der, det bliver jeg aldrig træt af, det kan næsten være lidt plagsomt at fordybe sig så meget. Ikke nok med at du kender en organisation, du vil kende menneskerne, de enkelte mennesker, forstå deres handlinger og hvordan de tænkte. For mig er essensen af historiefaget faktisk arbejdet med kilderne. Det synes jeg er utroligt fascinerende, det er det nærmeste du kommer fortiden. Det er at sidde med de skrifter, der blev til for 100 år siden, at prøve at tyde den ofte vanskelige håndskrift og lægge puslespillene. Jeg synes menneskenes måder at tænke på puster igennem disse papirer, noget som er utroligt fascinerede. Så der må jeg sige at lysten driver værket.

HRC: Men man skal så også lige have sluttet 
verket. Giver $d u$ arbejdet med kilderne en bestemt tid for du gair hjem og samler op og analyserer?

IB: Ja, det gør jeg, for hvis man driver med kilderne alt for længe og ikke får skrevet noget, så mister man interessen og man mister overblikket. Ofte giver det sig ganske let, fordi du har en tidsfrist. De ting du ikke skal aflevere til en bestemt tid, er ofte farlige, for de hænger for længe. Og der må man på et eller andet tidspunkt sige: enten har jeg gjort det her forgæves eller også bruger jeg det og det som det nu er. Så giver man sig selv nogle måneder eller en sommerferie eller et eller andet. Det kommer an på, hvor stort det er. Og det er jo ofte en pinefuld proces. Jeg tror aldrig jeg kommer ud over det stadium at når samlerglæden har hersket i mig længe og jeg skal til strukturere og lave en sammenfatning om de problemer, jeg nu ønsker at belyse, da er det pinefuldt. Begyndelsen er vældig hård. Men så kommer man i gang og så er der et eller andet der løsner sig. Jeg laver så at sige en slags torso eller et eller andet vældig groft og så begynder jeg at klippe ud og tage væk og sætte ind. En type arbejde, som faktisk har meget med en kunstnerisk skabelsesproces at gøre.

\section{HRC: Har du en let ved at skrive?}

IB: Jeg har let ved at skrive, når jeg er oplagt, ja, men jeg kan også sidde at slås med det. Hvis man ikke tænker klart så udtrykker man sig heller ikke klart, det dunkelt sagte er det dunkelt tænkte. Der kan komme for mange indfaldsvinkler til et stof. Det som rutinen giver er, at man ikke fortvivler i denne situation, man ved at dette er en fase, som hører med. Jeg bruger da den metode, at jeg holder på så længe, som jeg overhovedet kan og lægger det så væk. Lægger det væk en fredag og går tur og leger med børnebørn hele weekenden. Måske lægger jeg det væk en uge og så på et tidspunkt tager jeg det op igen. Jeg synes de allerfleste manuskripter tjener vældigt på at blive lagt væk en stund og så tage dem op på ny. Ikke for længe men så tilpas at man får noget andet ind $\mathrm{i}$ hovedet $\mathrm{og}$ kan læse dem med nye øjne.

HRC: Det er mit indtryk at du altid overholder deadlines. Hvordan bore du dig ad med det?

IB: Jeg er nok med årene blevet bedre til at sige nej, at nu er bægeret fuldt, nu er du nødt til at tømme det ud inden du siger ja til noget nyt. En anden mekanisme, som er kommet med årene det er at sige: nå ja, den artikel er ikke liv eller død, hvis den nu ikke bliver helt så god, som jeg gerne ville at den skulle være. Hvis der er noget som er uklart i den, så får det være. At være en lille smule large overfor sig selv, og sige: der var ikke mere tid, færdig med det. Som historiker, og det gælder muligvis al forskning, må man indse at man aldrig bliver helt tilfreds med det, man laver. Man kan altid finde på noget som burde være lavet anderledes. Det er et punkt, hvor det kan blive farligt, for så udtænker man nogle nye perspektiver, som ødelægger de gamle. Så det er noget med at sige stop Dele det op og sige,at nu er det er færdigt.

HRC: Hvorfor er der så få kvinder, som søger en karriere $i$ historifaget?

IB Når jeg har haft dygtige hovedfagsstudenter så har jeg altid opmuntret dem til at søge stipendium og fortsætte. Det er det de allerfærreste af kvinderne har gjort det. De ville ikke ind på et universitet, de syntes det var for verdensfjernt, der var for mange albuer - ja, måske var det for mandsdomineret? De ville hellere have et 9-4 job fremfor den livsform, hvor man aldrig har fred. De ville have et job, hvor de kunne have mand og barn ved siden af. Samfundets forventinger til kvinder og kvinders forventninger til sig selv er stadig noget anderledes end for mænd og det kan have en virkning på valg af karriere.

HRC: Hvordan har du oplevet mand og magt på universitetet? Og hvordan har $d u$ 
haft det med den magt, som du selv har haft? IB: Mit institut har været ret demokratisk Da det blev oprettet var det med vældig unge professorer. Men vi har jo haft vore slåskampe på mange felter. Men det er på en måde ikke gået så meget på køn selvom mændene var i helt klart flertal. Jeg var den eneste kvinde. Men i mange konfliktsituationer samarbejdede jeg da med flere af minde mandlige kolleger. Jeg synes at så længe magtkamp foregår med argumenter, så længe det er en diskussion, hvor man kan forsørge at finde frem til en løsning, så er det fint. Men er der nogle, som sidder med magten og bare sætter deres vilje igennem, det bryder jeg mig ikke om. Men det vil der altid være, både mænd og kvinder, og det kommer man ikke udenom. Det er heller ikke alle mænd, som bruger magt bare for at bruge den. Her er der ikke tale om klare kønsforskelle, men om at mænd er de fleste i et akademisk miljø. I den situation er man nødt til at bygge alliancer til dem som man kan samarbejde med, uanset køn.

Jeg har prøvet at undgå denne negative brug af magt, jeg har forsøgt at finde frem til konsensus i de sammenhænge, hvor jeg har samarbejdet. Skal man udføre et job sammen er det bedst at finde frem til en fælles vej. Det kan man ikke altid, men så må man forsøge at lave en atmosfere hvor man siger, nå, ja, du fik ret i dag, i morgen er det så min tur til at få noget igennem. At der ikke er nogen, der føler at de bliver skudt ud hele tiden, fordi magten sidder et bestemt sted. Når magten er flydende og snart snart her, snart der, så kan magt jo være meget positiv. Men der er situationer, hvor man ikke kan opnå konsensus, og da må man sige, at sådan bliver det. Der skal tages en beslutning. Men igen bør atmosfæren så være sådan, at det ikke sætter ondt blod for resten af livet. Jeg har da også desværre oplevet samarbejdsforhold, hvor det overhovedet ikke gik, og hvor der kun var en ting at gøre, nemlig at opløse samarbejdet.
HRC: Hvordan har du fået familieliv og karriere til at henge sammen?

IB: Det er lykkedes en vis. Når det drejer sig om parforhold er det aller vigtigste, at parret er enige om, at sådan skal det være. I Norge var det usædvanligt at gifte kvinder i min generation havde lønarbejde Jeg har tit talt med min mand om det, han har aldrig kunnet forstå de mænd, som har sat sig på bagbenene og forventet, at konen kun skulle yde noget hjemme og ikke gå ud. Som han siger, det bliver så meget mere interessant, så han har al mulig interesse i det. Og lige fra begyndelsen forstod nok også, at hvis han satte sig på bagbenene, så var det parforhold sluttet, det var nok også lidt derfor. Det er utrolig vigtig, at man i udgangspunktet er enige om, at det skal være sådan, og så må vi hjælpes ad. Begge parter giver jo noget, når man gør det sådan. For mange var og er det jo slet ikke så let at få til at hænge sammen.

Jeg begyndte i et halvtidsjob på Historisk Institut i Bergen, da jeg havde taget min eksamen og da havde jeg bitte små børn, tvillinger. På det halvtidsjob tjente jeg akkurat det som behøvedes for at betale en au pair pige.

Og så drejer det sig også om at gøre familien og hjemmet til et fælles foretagende, hvor alle gør noget. Og for at det skal fungere, så har jeg - selv om det af og til kunne være vanskeligt - sagt at week-enden er familiens. Og da børnene begynde at være oppe om aftenen, så var aftenen for børnene. Selvom jeg ikke var der om dagen, så var jeg der om aftenen. Så dette at man har nogle faste holdepunkter, hvor man ved, at familien er der og at man bruger tid på familien bevidst, det tror jeg er vældigt vigtigt. De få gange hvor jeg har arbejdet om søndagen, var jeg så træt mandag morgen, at jeg ikke fik gjort noget. Men hvis jeg derimod havde gået tur med ungerne, så var jeg frisk og oplagt mandag morgen . Så det har jeg altså vældig stor tro på, det der med at have halvanden eller to dage om ugen, som simpelthen er familiedage. Og 
der skal det ikke bare gælde den ene, det er ikke bare mor som skal gøre det, men der skal forældrene være sammen, og være sammen med deres børn. Det betyder vældigt meget, at man har det der frllesskab, tror jeg.

Samtidig mener jeg, at det parforhold, hvor den ene står og læner sig op ad den anden, det er et dårligt forhold. Begge parter bliver trætte af det. Står man overfor hinanden som selvstændige individer, så kan man give hinanden hænderne og samarbejde, og det har fungeret i mit tilfælde. Det at have sin uafhænighed og kunne hvile i sig selv, samtidig med at man selvfølgelig er afhængig af andre på det følelsesmæssige plan og sætter pris på venskaber og bånd. Venner og familie er jo ikke bare sådan noget, der er der. Du må gøre noget for at være sammen med dem, hvis det skal fungere. Men samtidig må man kunne trives med sig selv og klare sig selv.

\section{HRC: Har du flere store projekter på bed- ding?}

IB: Ja, noget af det jeg nu er optaget af, det er det med komparation. Det er meget vanskeligt, men jeg synest det er nyskabende at sammenligne kønsrealtioner i forskellige lande og i forskellige kulturer, det giver ny forståelse. Noget af det jeg syntes er væsentligt nu i historieforskningen, det er at komme ud over de nationale grænser.

\section{HRC: Er tiden lobet fra en Nordisk Kvinde- historie?}

IB: Jeg tror hellere jeg ville satse på temaområder og så trække køn ind som en systematisk variabel. Vi bør ikke overse hele det nye område med mandshistorie og maskulinitetsforskning og hvordan de to variable kvinde/mand - feminitet,/maskulinitet forholder sig til hinanden. Så i den forstand ville det være bedre at lave en fremstilling, som belyser kontinuitet og ændring i kønsrelationer og kønsidentiteter i de nordiske lande.
HRC: Du har fungeret som forbillede for de generationer, som kom efter dig. Har du selv haft nogle forbilleder?

IB: Der har ikke været nogen bestemt person, hverken kvinde eller mand, som har været mit forbillede egentlig. Men det jeg vel kan sige, er at der er ting, som jeg har vidst at jeg ikke ville opleve. Jeg ville ikke have min mors skæbne. Jeg ville ikke risikere at sidde uden at kunne klare mig selv økonomisk med fire børn, det stod for mig som en rædsel. Jeg så, hvor hårdt det var for hende og hendes forgxves forsøg på at komme ind på arbejdsmarkedet. Og hvor mange gange har jeg ikke hørt hende sige: "Havde jeg dog bare gjort min uddannelse færdig". Det at have et liv, hvor man er afhængig af andre, det er ikke noget godt liv. Man skal kunne stå på egne ben. Så det har jeg prøvet på at slås for.

\section{IDA BLOM:}

\section{Publikationer 1880-1996:}

Bibliografien er udarbejdet af Bente Rosenbeck i 1996.

\footnotetext{
- Barnbegrensning - synd eller sunn fornuft, 1980 . “Å få barn - skjebne eller valg? Motiver for barnebegrensning blant kvinner i Kristiania fra århundreskiftet til den annen verdenskrig". (Svensk) $\mathrm{Hi}$ storisk Tidsskrift, nr. 3, 1980.

. "The Struggle for Women's Suffrage in Norway 1885-1913". Scandinavian Journal of History, vol. 5, nr. 1, 1980.

- Kvinnen, et likeverdig menneske? Oslo, Aschehoug, 1981.

. "Sosialisering av barn i Norge på 1800-tallet. Teori, metode og kildebruk”. Dugnad, nr. 2-3, 1982.

. "Barselkvinnen mellom befolkningspolitikk, sosialpolitikk og kvinnepolitikk fra 1880-årene til 1940”. Historisk Tidsskrift, nr. 3, 1982.

. "A Centenary of Organized Feminism in Norway". Women's Studies International Forum, 5, nr. 6, 1992.

. "Prosjektforskning i kvinnehistorie". Tverfaglig humanistisk konferanse om kvinneforskning. Arbeidsnotat $1 / 83$. NAVFs sekretariat for kvinneforskning, Oslo 1983.
} 
. "Kvinner og samfunnsforandring. Politiske/ideologiske aspekter ved oppkomsten av kvinnehistorie/-forskning". Usynlig historie. Studier i historisk metode, 17, UF, 1983.

- Kvinner i Bergen Venstre. Streiftog gjennom Bergen Venstre i 100 àr, 1883-1983. Bergen, 1983.

. "Veien til juridisk likestilling. Hovedtrekkene i arbeids-, ekteskaps- og familielovgivningen i de nordiske land fra midten av 1800-tallet til ca. 1970". Historica IV. Studia Historica Jyväskyläensia 27, Jyväskylä 1983.

. "Barneoppdragelse på oldemors tid - et problem for dagens mødre?”. Kjønnsroller og likestilling. Bergen, 1983.

. "Frauenarbeit und Familienökonomie in der städtischen Gesellschaft Norwegens von 1875 bis 1930". Jahrbuch für Wirtschaftsgeschichte, 1984.

. "Ingen mor maa til tidsfordriv sitte med sitt barn paa fanget'. Konflikten mellom forsørgeransvar og omsorgsansvar blant ugifte mødre i Bergen 19161940”. I P. Fuglum og J. Simensen, red.: Historie nedenfra. Festskrift til Edvard Bull på 70-årsdagen. Oslo, Universitetsforlaget, 1984.

. "En liten ondskap?". O. Grepstad og J. Nerbøvik (red.): Venstre hundre år. Oslo, 1984. (Om Venstrekvinnene).

. "Family History and Women's History. The Case of Norway" I J. Rogers and H. Norman: The Nordic Family. Perspectives on Family Research. Essays on Social and Demographic History, No. 41985.

Uppsala Universitet (a).

. "Kvinnehistorie - ledd i historieforskningen og ledd i kvinneforskningen". Historisk Tidsskrift, nr. 4, 1985 (b).

. "Nødvendig arbeid - skiftende definisjoner og politiske konsekvenser". Historisk Tidsskrift, nr. 2, 1985 (c).

. “'Den haarde Dyst' - fødsler og fødselshjelp”. Kvinnenes kulturhistorie, Bind 1, 1985 (d). - Nordisk lovoversikt. Viktige lover for kvinner ca. 1810-1980. Redigert av Ida Blom og Anna Tranberg. Nordisk Ministerråd, 1985 (e).

. "Noen hovedlinjer gjennom lovverket fra 18- og 1900-tallet". Ida Blom og Anna Tranberg (red.): Nordisk lovoversikt. Viktige lover for kvinner ca. 1810-1980. Nordisk Ministerråd, 1985 (f).

. "Kvinneliv i vårt århundre". Kvinnenes kulturbistorie, Bind 2. Oslo, Universitetsforlaget, 1985.

. "Kvinneliv på attenhundretallet". Kvinnenes kulturhistorie, Bind 2. Oslo, Universitetsforlaget, 1985.

. "Kvinnehistorie - et fagfelt med tradisjoner". Materialisten, 1985.

- "Mentalitetshistorie og kvinnehistorie". I. Fredriksen og H. Rømer (red.): Kvinder, mentalitet, arbejde. Kvindehistorisk forskning $i$ Norden. Rapport fra det 2. nordiske kvindehistoriemøde 1985. Århus 1986.

. "Patriarkatsteorier i kvinnehistorisk forskning". Kjønn og makt: Teoretiske perspektiver. Arbeidsnotat 2/1987, NAVFs sekretariat for kvinneforskning og kvinner i forskning, og Nytt om kvinneforskning, nr. 2, 1987.

. "Really Excellent Men Do not Grow on Trees..." Breadwinning and Structures of Authority in Bourgeois Marriages around the Turn of the Century. Paper given at 2. Deutsch-Norwegishes Historikertreffen 28-31 Mai 1987. Conference report NAVF.

. “Hjernen kan ikke utvikle seg samtidig med ovarierne...'. Kvinnelige pionerer i den medisinske profesjon omkring 1900". B. Sawyer og A. Göranson (red.): Manliga strukturer och kvinnliga strategier. En bok til Gunbild Kyle. Göteborg 1987. “'smaa barn som prøveklut for alskens gammeldags husraad...'? Konflikt om ammerutiner i Bergen 1910-1940". Över gränser. Festskrift til Birgitta Odén. Lund 1987.

. "Women's Politics and Women in Politics in Norway since the End of the 19th Century". Scandinavian Journal of History, 12, nr. 1, 1987.

. "Kvinnehistorie - makt og misbruk". Underveis. Festskrift til Eva Kolstad. Oslo, 1988.

. "Den haarde dyst". Fødsler og fødselshjelp gjennom $150 \mathrm{a} r$. Oslo 1988.

. "Changing Gender Identities in an Industrializing Society: The Case of Norway". Gender and History, Vol. 2, 2, 1990.

. “'Hun er den raadende over Husets økonomiske Anliggender?'Changes in Women's Work and Family Responsibilities in Norway since the 1860's". W.R. Lee (ed.): Women's Work. Family Income and the Structure of the Family in Historical Perspective. Manchester Univ. Press 1990.

. "En anden historie - kvinnehistorie i et internationalt perspektiv". Historisk Tidsskrift 1990(4). . "Changing Gender Identities in an Industrializing Society: the Case of Norway. c. 1870c.1914". Gender and History 1990 2(2).

. "Ammerutiner- et stridsspørgsmål mellom læger og mødre?” Marit Krikevold m.fl-: Klokskap og kyndighet. Oslo, 1993.

. "Refleksjoner over grunntrekk i norsk historie". Historisk Tidsskrift 1992(3).

- "Global Women's history: Organizing Theories and Cross-Cultural Understanding". Offen, Pierson and Rendall (red.): Writing Women's History: International Perspectives. London, 1991.

- Foreword i Offen, Pierson and Rendall, 1991

. "Kommunal omsorg for mødre og småbarn i 
Bergen i første halvdel av 1900-tallet”. Anne Hilde Nagel (red.): Velferdskommunen. Kommunens rolle $i$ utviklingen av velferdsstaten. Bergen, 1991.

. "Voluntary Motherhood 1900-1930. Theories and Politics of Norwegian Feminists in an International Perspective".

- Gisela Boock, Pat Thane (ed.): Maternity and Gender Policies. Women and the Rise of the European Welfare States 1880s -1950s. London and New York, 1991.

. "Widowhood - From the Poor Law Society to the Welfare State. The Case of Norway 1987-

1964". Journal of Women's History, Vol 4, no. 2, 1992.

- Cappelens kvinnehistorie bd. 1-3. Oslo 1992 og 1993.

S. 9-13, 347-349, 547-561, 689-791. Desuden s. 7-13,111-229, 336-339 i bd.3) (a).

. "Kjønnssystem som et element i syntesedannelse". Marthinsen, Liv og Winge, Harald (red.): Syntese $i$ historieskrivningen. Oslo 1992.

. "On the Shelf? Single Women in Modern European History". Rekish Hyorom, 1992. (Også trykt i japansk historisk tidsskrift).

- Bente Rosenbeck: Kvindekøn og Kroppens politik (opposition). Historisk Tidsskrift, hefte 1, 1993 (a).

. "Om at skrive globalhistorie i dekonstruktionens tid". Konferanserapport fra det 4. nordiske kvinnehistoriemøte. Tampere, Finland, 27.-30. mai 1993 (b).

Også trykt i Kvinnovetenskaplig tidskrift, nr. 3, 1994.

. "En nasjon- to kjønn”. Historisk tidsskrift, 4, 1993.

. "Equality and the Threat of War". T.G. Fraser og Keith Jeffery: Men, Women and War. Historical Studies 18, Dublin, 1993.

. "Politikk og kjønn - nationalisme, forsvars-politikk og demokrati omkring 1900". Rapport III.

Fra kvinnehistorie til kjønnshistorie? Det 22. nordiske historikermøte. Oslo 13.-18. august 1994 (a). - Det er forskjell på folk - nà som for. Om kjønn og andre former for sosial differensiering. Oslo , 1994. 207 sider.

. "Fra det moderne til det postmoderne subjekt". Konstituering av kjønn. Udgivet af Norges Forskningsråd, 1995.
. "Refleksjoner over stat og kjønn". Nagel, AnneHilde.(red.): Kjonn og velferdsstat. Bergen, 1995. - Women's History. W.H. Hubbard a.o. (ed.): Making a Historical Culture. Historiography in Norway. Oslo-Copenhagen-Stockholm- Boston 1995. . "Zusammenwirken von Nationalismus und Feminismus um die Jarhhundertwende - Ein Versuch zu Vergleichender Geschlechtergeschichte". Gerhard Haupt und Jürgen Kocka: Europa in Vergleich. 1995.

. "Fra det moderne til det postmoderne subjekt". Nytt Norsk Tidsskrift, 2-1995

. "Cholera-Morbro'er og Danmark". Historie, nr. 1, 1995 (a).

. "Sentrale aspekter på kvinne - og kjønnshistorie". General and Applied Culturology, 1995. (Også trykt på bulgarsk).

\section{PUblikASJONER 1996 Og 1997:}

. "Das Zusammenwirken von Nationalismus und Feminismus um die Jahrhundertwende - Ein Versuch zur vergleichenden Geschlechtergeschichte, in Heinz-Gerhardt

Haupt und Jürgen Kocka, red. Geschichte und Vergleich. Ansätze und Ergebnisse international vergleichender Geschichtsschreibung. Campus Verlag, Frankfurt/New York 1996, ss.315-338.

. "Nation-Class - Gender : Scandinavia at the Turn of the Century", i Scandinavian Journal of History, vol. 21,Spring, 1996, ss.1-16.

- "World History ad Gender History : The Case of the Nation State", i: Stein Tønnessen m.fl., Between National Histories and Global History. Konferanserapport til 23. det nordiske historikermite, FHS Helsingfors 1997, ss. 71-92.

. "Kommune og frivillige organisasjoner i kamp mot tuberkulosen. Bergen 1900 - 1920" i Stale Dyrvik m.fl., (red.), Festskrift til Historisk institutts 40-års-jubileum, Bergen 1997

. "Sentrale aspekter på kvinne- og kjønnshistorie" IB intervjuet av Krassimira Daskalova, oversatt til bulgarsk i Newsletter of the Bulgariahn Women's Studies Association, 1997. Tidligere publisert, se 1995 